\title{
Urgensi Majelis Taklim Sebagai Lembaga Dakwah \\ di Masyarakat
}

\section{Mujahidin}

UIN Antasari Banjarmasin DPK IAIS Sambas

\begin{abstract}
The existence of majlis taklim in society becomes very important. This is because the assembly taklim has a position and a strategic role, in conveying the values of da'wah in the community more specifically to the mothers of the religious sciences. In addition, the assembly became a means of communication and means to strengthen the fraternity among fellow Muslims. In addition, the assembly taklim can serve as a medium in the mental mental development of Islamic societies in the face of the current era of information globalization. Therefore it can be used as a medium of enlightenment and community empowerment. In other words, the existence of majelis taklim generally can be utilized by all circles of society as non-formal education institutions.
\end{abstract}

Keyword: Assembly Taklim, Da'wah, Society

\section{Pendahuluan}

Perkataan majelis taklim berasal dari bahasa Arab dari kata majelis dan taklim. Majelis artinya tempat, dan taklim artinya pengajaran atau pengajian. Dengan demikian, secara lughawi atau bahasa majelis taklim adalah tempat untuk melaksanakan pengajaran atau pengajian agama Islam. Perkembangan selanjutnya menunjukkan bahwa majelis taklim tidak hanya terbatas sebagai tempat saja, tapi lebih maju lagi menjadi lembaga atau institusi yang menyelenggarakan pengajaran atau pengajian (KODI, 1990: 5).

Musyawarah majelis taklim se-DKI Jakarta yang berlangsung tanggal 9-10 Juli 1980 memberikan batasan majelis taklim adalah 
lembaga pendidikan nonformal Islam yang memiliki kurikulum sendiri, diselenggarakan secara berkala dan teratur dan diikuti oleh jama'ah yang relatif banyak; dan bertujuan untuk membina dan mengembangkan hubungan yang santun dan serasi antara manusia dengan Allah SWT, antara manusia dengan sesamanya, dan antara manusia dengan lingkungannya, dalam rangka membina masyarakat yang bertaqwa kepada Allah SWT. (KODI, 1990: 5). Dari definisi tersebut dapat ditarik kesimpulan bahwa: (a) Majelis taklim adalah lembaga pendidikan nonformal Islam, (b) Waktu belajarnya berkala tetapi teratur, tidak setiap hari seperti sekolah atau madrasah. Pengikutnya disebut jama'ah (orang banyak) bukan pelajar atau murid. Hal ini didasarkan karena kehadiran di majelis taklim bukan merupakan kewajiban sebagaimana kewajiban murid menghadiri sekolah atau madrasah, (c) Tujuannya lebih khusus lagi, yakni langsung dikaitkan dengan memasyarakatkan ajaran Islam.

Ditinjau dari aspek sejarah, sebagaimana dikemukakan oleh Tutty Alawiyah AS (1997: 91), istilah majelis taklim muncul dari sebuah pengajian yang diasuh oleh K.H. Abdullah Syafi'ie (ayah dari Tutty Alawiyah). Pengajian tersebut muncul pada tahun 1965 di masjid Al-Barkah, khususnya dalam menangkal pengaruh PKI di Indonesia. Dari masjid Al-Barkah, K.H. Abdullah Syafi'ie mengembangkan pengajian yang disebutnya majelis taklim, baik untuk kaum bapak maupun yang dikhususkan untuk kaum ibu. Akhirnya istilah majelis taklim menjadi trade mark dari pengajian-pengajian K.H. Abdullah Syafi'ie. Sebelum itu orang kalau mau menghadiri pengajian tidak pernah menyebut nama majelis taklim, tetapi lebih suka menyebut mau pergi ke pengajian.

Lebih lanjut Tutty Alawiyah (1997: 92) menyatakan bahwa penamaan majelis taklim akhirnya melahirkan identitas tersendiri 
yang membedakannya dengan pengajian umum biasa, yaitu sifatnya yang tetap dan berkesinambungan. Akhirnya terbukti bahwa kegiatan yang bersifat majelis taklim itu menjadi kebutuhan masyarakat Islam baik di kota-kota yang sibuk maupun di desa-desa yang terpencil. Kenyataan ini menumbuhkan gagasan untuk mengkoordinasikan mereka dalam wadah yang tidak mengikat terkecuali ikatan tanggung jawab dakwah dan ukhuwah (persaudaraan). Selanjutnya pada tanggal 1 Januari 1981 berdirilah organisasi kontak yang disebut Badan Kontak Majelis Taklim (BKMT).

Masih menurut Tutty Alawiyah (1997: 94-95), dari pengalaman selama ini, majelis taklim merupakan tempat berkumpul, tempat belajar dan tempat bermasyarakat kaum ibu. Sambil berkumpul, waktu yang tersedia diisi dengan bersama membaca Al-Quran. Sebagai tempat belajar khusus kaum ibu, mereka mendapat pelajaran agama dari seorang atau beberapa orang guru tetap. Dalam kesempatankesempatan tertentu, mereka memperingati hari-hari besar Islam. Acara ini biasanya diisi dengan ceramah mubalig atau mubaligah undangan. Di samping itu, majelis taklim juga sering mengadakan kegiatan sosial seperti memberi santunan uang kepada anak yatimpiatu, kunjungan ke panti asuhan dan jompo dan sebagainya.

Kehadiran majelis taklim di Indonesia beberapa dekade terakhir ini harus diakui telah memberikan kontribusi yang cukup signifikan dalam pelaksanaan dakwah Islam. Hal ini dapat kita saksikan dari keberadaan majelis taklim yang telah sampai ke tingkat masyarakat paling bawah, yaitu di pedesaan. Sementara itu, secara organisatoris majelis taklim telah memiliki struktur organisasi dan kepengurusan yang teratur berupa Badan Kontak Majelis Taklim (BKMT) mulai dari tingkat pusat, provinsi, kabupaten/kota, dan kecamatan. 


\section{Pembahasan}

\section{Aspek-aspek dalam Berdakwah}

Ada beberapa aspek yang perlu diperhatikan dalam kegiatan dakwah, di antaranya adalah peran pemimpin. Bagaimana peran seorang pemimpin dalam kegiatan dakwah -termasuk dalam majelis taklim- dapat dilihat dalam kutipan berikut: "peran pemimpin, yaitu orang-orang yang memiliki nilai-nilai kepemimpinan dan kemampuan atau keahlian manajemen itu sangat menentukan bagi keberhasilan penyelenggaraan dakwah" (A. Rosyad Shaleh, 1993: 37). Secara lebih khusus M. Arifin mengungkapkan bahwa seorang pemimpin adalah orang yang dapat menggerak kan orang lain disekitarnya untuk mengikutinya. Pemimpin dakwah adalah orang yang dapat menggerakkan orang lain yang ada di sekitarnya untuk mengikutinya dalam proses mencapai tujuan dakwah “(M. Arifin, 1997: 89).

Aspek berikutnya yang perlu diperhatikan dalam kegiatan dakwah adalah sikap kepengikutan (followership). Dalam hubungannya dengan sikap kepengikutan, di kalangan masyarakat dikenal ada tiga sebab psikologis, yaitu:

1. Adanya dorongan mengikuti pemimpin sehingga weerstand atau resistensi (daya tahan) dari orang-orang untuk mengikutinya dengan mudah dapat dilalui.

2. Adanya sifat-sifat khusus pada para pemimpin yaitu sifat-sifat dan ciri-ciri kepemimpinan yang mampu mempengaruhi jiwa orang lain sehingga tertarik kepadanya.

3. Adanya kemampuan pada diri pemimpin untuk menggunakan teknik atau metode kepemimpinan (M. Arifin, 1997: 90).

Adapun tipe-tipe kepengikutan, sebagaimana diungkapkan M. Arifin (1997: 90-91) ada lima tipe, yaitu:

1. Kepengikutan karena naluri; 
2. Kepengikutan karena tradisi atau kebiasaan;

3. Kepengikutan karena agama;

4. Kepengikutan karena rasio; dan

5. Kepengikutan karena peraturan atau hukum

Berkaitan dengan tipe-tipe kepengikutan, dalam Al-Quran sudah jelas disebutkan bahwa setiap orang yang beriman diwajibkan untuk mentaati Allah, Rasul dan ulil amri. Sebagaimana firman Allah dalam surah An-Nisa' ayat 58 berikut ini:

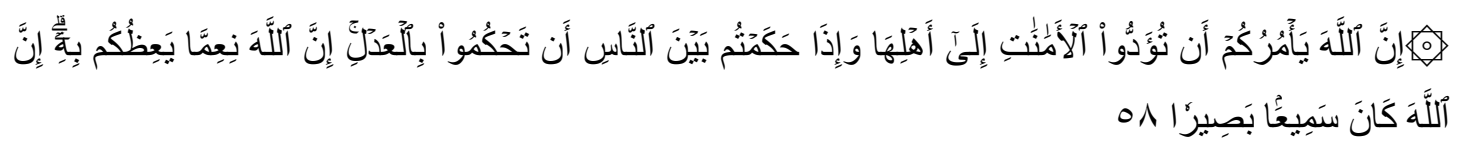

Artinya: "Hai orang-orang yang beriman, taatilah Allah dan taatilah Rasul-Nya, dan ulil amri diantara kamu."

Majelis taklim dapat dikategorikan sebagai sebuah organisasi dakwah. Sebagai sebuah organisasi, maka aspek manajemen merupakan suatu hal yang cukup memegang peranan penting dalam pencapaian tujuan organisasi. Demikian pula halnya dengan keikutsertaan anggota majelis taklim dalam setiap kegiatan, tentunya terpengaruh pula oleh faktor manajemen. Baik buruknya manajemen majelis taklim juga akan berdampak pada keikutsertaan anggota dalam kegiatan. Untuk melihat sejauh mana peran manajemen dalam suatu kegiatan dakwah dapat dipahami dari kutipan berikut ini:

Proses dakwah yang mencakup segi-segi yang begitu luas, hanya dapat berjalan dengan lancar dan berhasil baik, bilamana tersedia tenaga-tenaga pelaksana yang cukup serta masing-masing memiliki kemampuan dan keahlian yang diperlukan. Di samping itu adanya tenaga-tenaga yang cukup dan berkemampuan tadi barulah efektif setelah mereka diorganisir dan dikombinasikan sedemikian rupa dengan faktor-faktor lain yang diperlukan. Sebab bila tidak, tenaga- 
tenaga yang bermacam-macam tadi cenderung untuk memperturutkan kemauannya sendiri-sendiri. Dan bilamana hal ini sampai terjadi, maka akibatnya adalah timbulnya kesimpangsiuran, kekacauan, kekosongan dan kekembaran dalam melaksanakan kegiatan-kegiatan dakwah, yang pada gilirannya akan mengakibatkan kegagalan bagi proses dakwah itu. Demikian pula faktor-faktor lain yang diperlukan dalam proses dakwah, seperti misalnya fasilitas dan lain sebagainya, haruslah dapat dihimpun dan dikerahkan serta diatur penggunaannya sesuai dengan keperluan dalam rangka pencapaian tujuan dakwah yang telah ditetapkan (A. Rosyad Shaleh, 193: 32-33).

Kegiatan menghimpun dan mengerahkan serta mengatur sumberdaya yang ada, sebagaimana disebutkan di atas, lazim disebut kegiatan majamemen.

Aspek berikutnya yang perlu diperhatikan dalam proses dakwah adalah materi yang disampaikan atau yang dipelajari. Dalam sebuah kegiatan majelis taklim, materi yang dipelajari atau yang disuguhkan turut mempengaruhi antusias tidaknya anggota untuk ikut serta. Jika materi atau acara yang dijalani anggota dapat memenuhi atau sesuai dengan kebutuhan mereka, maka anggota tersebut akan merasa betah untuk secara terus menerus mengikuti kegiatan majelis taklim. Hal ini merupakan pemaknaan dari teori (psikologi) Maslow tentang kebutuhan. Teori Maslow tersebut adalah bahwa: motive manusia senantiasa menggerakkannya kepada pemenuhan akan kebutuhankebutuhan yang bertingkat sebagai berikut: (a) Pemenuhan kebutuhan fisiologis (jasmaniah), (b) Pemenuhan kebutuhan security (keamanan) dan perlindungan, (c) Pemenuhan kebutuhan hidup kemasyarakatan (sosial), (d) Pemenuhan kebutuhan akan pengakuan, (e) Pemenuhan kebutuhan akan kepuasan. Dalam proses kegiatan dakwah, pemenuhan akan kebutuhan-kebutuhan hidup manusia menurut 
teori di atas adalah mutlak perlu diperhatikan, oleh karena tanpa dapat menghampiri motive-motive pokok manusia, pesan dakwah mustahil dapat mempengaruhi perilaku obyek dakwah sebagaimana diharapkan (M. Arifin, 1997: 54).”

Selanjutnya M. Arifin (1997:58-63) menyebutkan lima macam motif atau dorongan kejiwaan yang mempengaruhi tingkah laku manusia. Pertama, motif yang mendorong aktivitas pribadi yang disebut oleh Goldstein self-actualization. Kedua, motif kepada keamanan atau disebut security motive. Ketiga, motif untuk mengadakan response. Keempat, motif untuk mendapatkan pengakuan di dalam kelompok atau masyarakat di mana ia hidup. Dan kelima, motif yang mendorong mencari pengalaman baru. Jika kita memaknai proses dakwah termasuk kegiatan dalam majelis taklim adalah sebuah sistem, maka metode penyampaian atau cara yang dipakai dalam kegiatan pengajian merupakan salah satu komponen dakwah yang mutlak diperhatikan. Kejelian memilih metode dalam pengajian akan turut menentukan minat dan antusiasme anggota dalam keikutsertaannya mengikuti kegiatan. Berkaitan dengan hal ini, Allah berfirman dalam surah An-Nahl: 125 sebagai berikut:

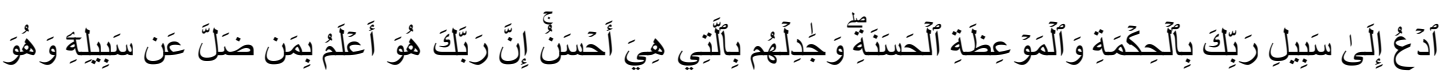

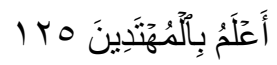

Artinya: "Serulah ke jalan Tuhanmu dengan hikmah dan pelajaran yang baik. Dan berdebatlah dengan cara yang baik."

Dalam sebuah hadits juga dinyatakan: "Permudahlah dan jangan kamu persulit; gembirakanlah dan jangan kamu mengatakan sesuatu yang menyebabkan ia lari dari padamu."

Hadits di atas merupakan salah satu pesan Nabi kepada utusannya Abu Musa Al Asy'ari dan Muadz ibn Jabal ketika hendak 
berangkat ke Yaman menunaikan misi dakwah yang ditugaskan oleh Rasulullah kepadanya. Pesan tersebut mengandung nilai motivatif dan persuasif terhadap orang lain tentang kebenaran yang disampaikan kepadanya. Atas dasar pesan demikian maka pihak-pihak yang menerima ajakan (dakwah) akan terbangkitlah dalam dirinya suatu daya rangsang terhadap kebenaran dakwah dengan sukarela. Situasi dan kondisi demikian baru dapat berkembang bilamana motivasi terhadap tingkah laku dalam proses dakwah tersebut benar-benar mengenai sasarannya. Di sinilah pentingnya mengetahui metode atau cara penyampaian dakwah yang efektif dan efisien. Begitu juga dengan penetapan lokasi (lingkungan) di mana kegiatan majelis taklim akan dilaksanakan juga mempengaruhi keikutsertaan anggota dalam kegiatan pengajian. Abd. Rosyad Shaleh (1993: 75) menyebutkan bahwa: "Ketepatan dalam penentuan dan pemilihan lokasi mempunyai pengaruh bagi kelancaran jalannya proses dakwah."

\section{Majelis Taklim sebagai Media Dakwah}

Sebagai sebuah media atau sarana dakwah, majelis taklim biasanya melaksanakan kegiatan seperti pembacaan shalawat Nabi, pembacaan surah Yasin, belajar membaca Al-Quran (tajwid), belajar ibadah (fiqh ibadah), belajar aqidah dan akhlak, dan terkadang diisi dengan wiridan khusus seperti membaca doa tahlil dan sebagainya. Meskipun bentuk kegiatannya terkesan monoton dan tidak terlalu mendalam dalam proses pembahasan suatu hal, tetapi para anggotanya tetap setia mengikuti rangkaian kegiatannya. Sebagai selingan, terkadang kegiatan majelis taklim diisi dengan ceramah atau tabligh agama dengan materi tertentu dengan menghadirkan pembicara yang berkompeten. Bahkan tak jarang untuk menarik minat para anggotanya, diadakan arisan. Ditinjau dari aspek 
keanggotaan, umumnya majelis taklim beranggotakan kaum perempuan, khususnya para ibu dari berbagai golongan strata sosial. Sebaliknya ada pula majelis taklim yang beranggotakan kaum lakilaki. Jumlah anggota pada setiap kelompok majelis taklim, yang tercermin dalam setiap melaksanakan kegiatan, umumnya berkisar antara puluhan sampai seratus orang. Pengelompokan majelis taklim biasanya didasarkan pada lokasi tempat tinggal, profesi, dan organisasi.

Beberapa nilai positif itu antara lain memupuk sikap musyawarah dan kegotongroyongan, adanya kesetaraan dan persaudaraan, sebagai tempat mencari ilmu pengetahuan, dan sebagai sarana melatih kemahiran membaca surah yasin dan tahlil. Nilai-nilai positif tersebut merupakan beberapa temuan yang telah diperoleh peneliti dari proses pengamatan, dan telah dipaparkan pada bagian terdahulu. Nilai-nilai tersebut tentunya sangat bermanfaat bagi anggota masyarakat yang mengikuti kegiatan majelis taklim. Dan karena manfaat tersebut, maka mereka tetap setia dan antusias mengikuti kegiatan majelis taklim. Hal ini sejalan dengan fungsi majelis taklim sebagai lembaga pendidikan non formal (KODI, 1990:8).

Hal tersebut didukung oleh pendapat Quraish Shihab di atas, dapatlah dimengerti bahwa pada dasarnya kehadiran anggota masyarakat dalam majelis taklim Al-Hidayah adalah untuk mengamalkan ajaran agama Islam, bentuknya adalah menyambung hubungan antar sesama ibu-ibu dari berbagai daerah yang berjauhan. Melalui kegiatan majelis taklim para ibu dapat menjalin hubungan yang selama ini putus atau belum tersambung sama sekali dalam arti belum saling kenal. Dengan tersambungnya ikatan kasih sayang antar para ibu, maka ukhuwah Islamiyah semakin erat. Menurut Quraish Shihab (1996:487) ukhuwah Islamiyah berarti "persaudaraan yang 
bersifat Islami atau yang diajarkan oleh Islam." Persaudaraan yang dipererat jalinannya dalam hal ini adalah persaudaraan antar sesama mukmin. Ajaran tentang persaudaraan antar sesama mukmin ini secara tegas dan jelas disebutkan dalam Al-Quran surah Al-Hujurat ayat 10 berikut:

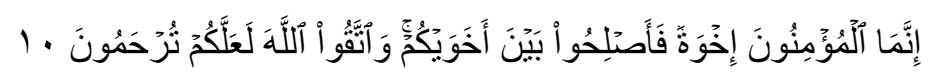

Artinya: "Sesungguhnya orang-orang mukmin bersaudara, karena itu lakukanlah ishlah di antara kedua saudaramu".

Faktor berikutnya yang banyak dikemukakan oleh informan adalah keinginan untuk menuntut ilmu, terutama ilmu agama. Menuntut ilmu tidak diragukan lagi merupakan salah satu ajaran Islam. Hal ini dapat dipahami dari banyaknya kata "ilmu" diulangulang dalam Al-Quran. Menurut Quraish Shihab (1996:434) kata ilmu dengan berbagai bentuknya terulang 854 kali dalam Al-Quran. Lebih lanjut Shihab menyebutkan bahwa dalam pandangan Al-Quran, ilmu adalah keistimewaan yang menjadikan manusia unggul terhadap makhluk-makhluk lain guna menjalankan fungsi kekhalifahan. Manusia, menurut Al-Quran, memiliki potensi untuk meraih ilmu dan mengembangkannya dengan seizin Allah. Karena itu bertebaran ayat yang memerintahkan manusia menempuh berbagai cara untuk mewujudkan hal tersebut. Allah juga memerintahkan kepada manusia untuk berlomba-lomba dalam mengerjakan kebajikan. Berkali-kali pula Al-Quran menunjukkan betapa tinggi kedudukan orang-orang yang berpengetahuan. Sebagaimana termaktub dalam Al-Quran surah Al-Mujadilah ayat 11 berikut:

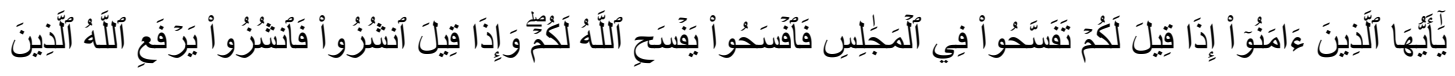

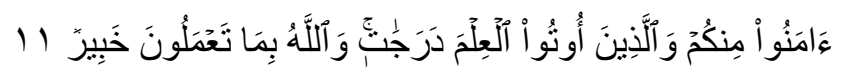


Artinya: "Allah akan meninggikan orang-orang yang beriman diantaramu dan orang-orang yang diberi ilmu pengetahuan beberapa derajat."

\section{Simpulan}

Kehadiran anggota masyarakat mengikuti kegiatan majelis taklim sesungguhnya didorong oleh semangat mengamalkan ajaran Islam yaitu menuntut ilmu. Demikian juga faktor ingin meningkatkan keimanan sebagai bekal di hari akhir nanti, merupakan dorongan yang bersifat keagamaan. Demikian pula halnya dengan faktor keempat yaitu ingin mendapatkan bimbingan dan tuntunan dalam membina rumah tangga juga merupakan pengamalan ajaran Islam. Berkaitan dengan keluarga, Quraish Shihab (1992: 253) menyatakan bahwa demi terpeliharanya kehidupan keluarga yang harmonis dan dapatnya unit terkecil dari satu bangsa itu menjalankan fungsinya dengan baik, Islam melalui syariatnya menetapkan sekian banyak petunjuk dan peraturan. Untuk mendapatkan petunjuk tersebut, para ibu mengikuti kegiatan majelis taklim. Ada sejumlah manfaat yang diperoleh anggota masyarakat dari mengikuti majelis taklim. Pertama, menambah ilmu pengetahuan, khususnya di bidang agama Islam. Kedua, mendorong peningkatan amal ibadah. Ketiga, membantu dalam upaya pembinaan keluarga dan generasi muda. Keempat, mempererat silaturrahmi antar sesama Muslim. Kelima, memberikan ketenteraman dan ketenangan batin. Dan keenam, dapat dijadikan sebagai lembaga pendidikan nonformal.

\section{Daftar Pustaka}

Tutty Alawiyah, (1997), Strategi Dakwah di Lingkungan Majelis Taklim, Bandung: Mizan. 
Koordinasi Dakwah Islam (KODI) DKI Jakarta, (1990), Pedoman Majelis Taklim, Jakarta: KODI DKI Jakarta.

Abd. Rosyad Shaleh, (1993), Manajemen Dakwah Islam, Jakarta: Bulan Bintang

M. Arifin, (1997), Psikologi Dakwah: Suatu Pengantar Studi, Jakarta: Bumi Aksara.

M. Quraish Shihab, (1992), Membumikan Al-Quran, Bandung: Mizan. 